\title{
Mapa como mediador na interpretação do território: O caso de Ouro Preto (MG, Brasil)
}

\author{
Map as a mediator in the territory of interpretation: \\ The case of Ouro Preto (MG, Brazil)
}

\author{
Mapa como mediador de la interpretación en el territorio: \\ El caso del Ouro Preto (MG, Brasil)
}

\author{
Cleidison Vieira de Rezende ${ }^{1}$ \\ Patrícia G. O. Rodrigues ${ }^{2}$
}

\begin{abstract}
Resumo: O turismo é um fenômeno econômico, político, social e cultural que deve ser estudado de modo especial pela cartografia, através da sistematização de uma cartografia do turismo, na qual o mais importante não é somente projetar símbolos para compor a legenda, e sim refletir sobre como esta deve ser organizada, a fim de expor claramente o raciocínio correto sobre o fenômeno, comunicando a verdadeira informação ao público que se utiliza desses mapas. Assim, buscou-se entender as possíveis deficiências e facilidades de interação dos turistas com os mapas turísticos de Ouro Preto-MG. Para tanto, o trabalho consistiu de referências e discussões teóricas que foram seguidas por uma análise de três diferentes mapas turísticos disponíveis sobre Ouro Preto, onde foi realizado o levantamento desses, sua abrangência e locais de divulgação. Com isto, esperou-se contribuir com a discussão sobre o mapa enquanto elemento mediador das experiências turísticas.
\end{abstract}

Palavras-chave: Turismo; Cartografia; Mapas turísticos; Símbolos; Ouro Preto (MG, Brasil).

Abstract: Tourism is an economic, political, social and cultural phenomenon that should be studied in particular by cartography, through the systematization of cartography of tourism, in which the most important design is not only the symbols to compose the legend, but also the reflection on how it should be organized, in order to clearly explain the correct reasoning about the phenomenon, with real information to the public who use those maps. Thus, it tries to understand the possible disabilities and ease of interaction of tourists with maps of Ouro Preto (MG). To this end, the work consisted of references and theoretical discussions that were followed by an analysis of three different tourist maps available in Ouro Preto, where was the survey of those, its scope and places of disclosure. With this, it is expected to contribute to the discussion about the map as a mediator of tourist experiences.

Keywords: Tourism; Cartography; Tourist maps; Symbols; Ouro Preto (MG, Brazil).

\footnotetext{
${ }^{1}$ Mestrando em Geografia pela Universidade Federal de Santa Maria (UFSM). Graduado pela Universidade Federal de Ouro Preto (UFOP). E-mail: cvr.geop@gmail.com

${ }^{2}$ Universidade Federal de Santa Maria (UFSM).E-mail: patirodrigues_85@hotmail.com
} 
Resumen: El turismo es un fenómeno económico, político, social y cultural que debe ser estudiado en particular, por la cartografía, a través de la sistematización de la cartografía del turismo, en el que el diseño más importante no es sólo símbolos para componer la leyenda, pero reflexionar sobre como debería se organizar, con el fin de explicar con claridad las razones correcto acerca del fenómeno, con información real para el público que si utiliza los mapas. Por lo tanto, tratar de comprender las posibles discapacidades y la facilidad de interacción de los turistas con mapas de Ouro Preto (MG, Brasil). Con este fin, el trabajo consistió en referencias y discusiones teóricas que fueron seguidos por un análisis de tres diferentes mapas turísticos disponibles en Ouro Preto, que era la eliminación de aquellos, su alcance y los lugares de la divulgación. Con esto, se espera que contribuya a la discusión sobre el mapa como un mediador de la experiencia turística.

Palabras clave: El turismo; Cartografía; Mapas turísticos; Símbolos; Ouro Preto (MG, Brasil).

\section{INTRODUÇÃO}

O turismo é uma atividade que comercializa o espaço, e a cartografia é o principal meio de representar tais ambientes. Por serem os mapas meios de comunicação entre o território e o turista, e seus símbolos importante elementos característicos, sem os quais nada se compreende (Pereira, Dias, \& Damolin, 1999), é que se propôs analisar os modelos de determinados mapas turísticos da cidade de Ouro Preto e suas possíveis relações com seus usuários.

Dessa forma, objetiva-se compreender as possíveis deficiências e facilidades de interação dos turistas com os mapas da cidade. A metodologia adotada consiste em pesquisas qualitativas dos principais mapas turísticos de Ouro Preto, onde, mediante embasamento teórico, buscou-se observar e analisar esse material a fim de que se possa obter um maior número de informações complementares para a produção de um material cartográfico temático do turismo.

Após o entendimento dos elementos que compõem a cartografia, surge a necessidade de apresentar os elementos constituintes de um material cartográfico exclusivamente turístico, dentro do conceito de uma cartografia voltada para esse setor. Portanto, para uma análise no caso de Ouro Preto, buscou-se entender o espaço turístico da cidade, bem como os materiais cartográficos com maior representatividade. Com isto, o que se vislumbra é a geração de uma base de conhecimento para, futuramente, propor um mapa com pretensões idealistas, no que tange à localização para os turistas.

Embora existam diferentes representações cartográficas bem elaboradas, há, porém, muito que se desenvolver nesta área do turismo, uma vez que tais mapas são, na maioria das vezes, elaborados sem a visão e orientações de turismólogos que, por formação, são capazes de melhor compreender os anseios e necessidades dos turistas em visita a uma região. Dessa forma, surge a necessidade de analisar os atuais modelos de mapas turísticos, a fim de contribuir para uma maximização de suas funções.

Assim, discute-se no presente trabalho a necessidade de um mapa bem elaborado que apresente diversos fatores de identificação e seus símbolos cartográficos adequados, para uma melhor localização daquele que irá utilizá-lo. 


\section{CARTOGRAFIA E TURISMO}

Os primeiros relatos do surgimento da cartografia incidem com as culturas primitivas, mais precisamente com os homínidas, povos que se diferenciavam dos primatas pela sua postura vertical e a produção de ferramentas. Tais povos desenvolveram a relação de espaço a partir de um eixo alto-baixo, no qual organizavam seu espaço ao redor do corpo humano e assim as noções de frente e trás, direita e esquerda e cima e baixo. Cáceres (1996) reafirmava essa condição espacial dos homínidas que permitia a estes dividir seus territórios e habitações. Esses povos, ao passarem da vida nômade para a sedentária e posteriormente com a criação dos animais domésticos, tiveram a necessidade de traçar os itinerários que povos percorriam para levar o gado às zonas de pastagem e também nos seus grandes deslocamentos que se faziam necessários no curso das estações (Aguilar, 1967).

No Brasil, a história da cartografia é reflexo das técnicas cartográficas portuguesas, uma vez que o governo português já estava além de muitos outros na ciência da cartografia, devido às grandes navegações no século XV (Aguilar, 1967). Com a descoberta do Brasil e chegada dos portugueses pelo litoral nordestino, houve necessidade de exploração do vasto território no intuito da descoberta de riquezas naturais e, consequentemente, metais preciosos. Duque e Mendes (2006) lembram que o governo português dedicou importante atenção à documentação cartográfica do Brasil, principalmente no que diz respeito ao limite com a América Espanhola, que poderia se tornar uma ameaça às suas terras. Finalmente, a então história cartográfica mais recente remete à associação da cartografia à geografia, que se tornou mais humana e não somente conexa ao estudo da terra. Assim, somaram-se aos marcos da cartografia os mapas climatológicos, geológicos, hidrográficos e àqueles com características humanísticas, como distribuição de raças, religiões, etnias etc.

Nas suas técnicas atuais, a cartografia tem grande apelo simbólico, uma vez que os símbolos constituem-se de comunicação não verbal, onde para decodificar sua mensagem é necessário identificar o signo e a sintaxe que o constituem e the dão realidade. $O$ signo corresponde a uma combinação de um significante (conceito) e um significado (imagem mental), e a sintaxe compreende as relações que as palavras estabelecem entre si nas orações e as relações que essas estabelecem entre si nos períodos. Chaui (1997) salienta que a "linguagem simbólica" realiza-se principalmente como imaginação, oferecendo sínteses imediatas (imagens), e seu outro tipo, a "linguagem conceitual", procura evitar a analogia e a metáfora, esforçando-se para dar às palavras um sentido direto e não figurado.

Dessa forma, surge a proposta dos símbolos cartográficos para o turismo, onde as fotografias ou desenhos representativos têm importante participação na elaboração dos signos iconográficos, que seria a representação por imagens (Figura 1). Dessa forma, por meio dos traçados, desenhos, cores e fotografias, os mapas são fontes simbólicas com a função principal de informar, devendo ater-se esses elementos apenas às finalidades a que se destinam (Morandi, \& Gil, 2002). 


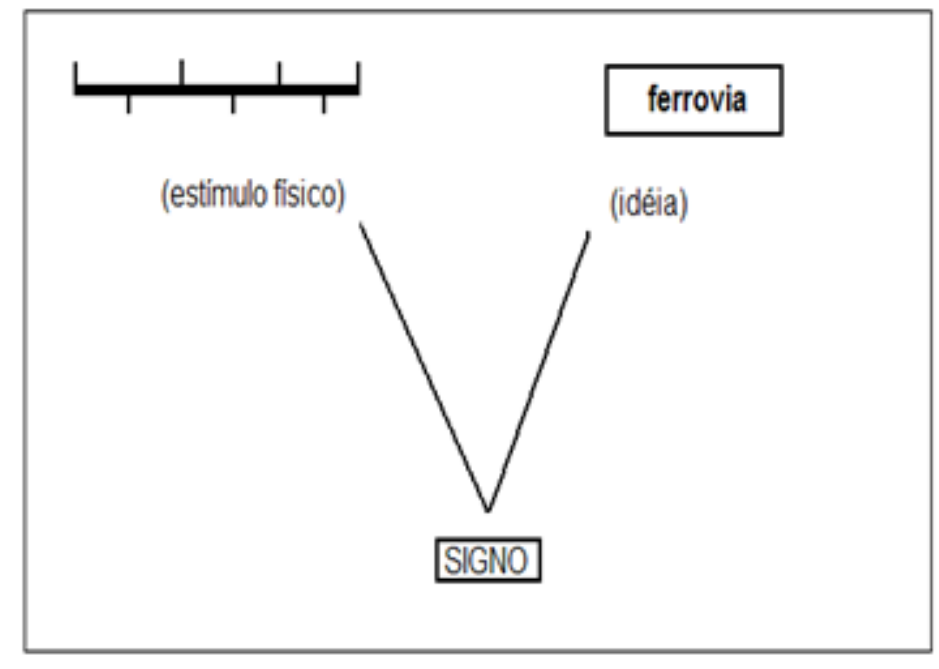

Figura 1. Signo: ideia associada ao estímulo

Fonte: Duarte (1991, p. 27).

Considerando o mapa como um importante meio para a locomoção de turistas, no mesmo deve conter as devidas ligações que favoreçam a interação entre os nós (pontos turísticos) e as linhas (itinerário percorrido). No entanto, os pontos turísticos apresentam-se normalmente num contexto geral, que pela proximidade entre os atrativos, induz o turista a fazer suas próprias ligações, traçando seu próprio itinerário. Além disso, grande parte dos mapas turísticos elimina possibilidades extras de locomoção, uma vez que nem todas as linhas (ruas, becos, praças etc.) são apresentadas e, dessa forma, extingue a utilização de novos caminhos.

Desse modo, a necessidade da utilização dos símbolos nas produções cartográficas é fundamental, pois enriquecem os mapas e constituem-se como fator somatório para modernização da produção dos mesmos. Como apresentado anteriormente em seu histórico, os mapas adquiriram, ao longo do tempo, subsídios que facilitaram a sua utilização: de uma placa de barro cozido passou a um complexo emaranhado de informações, imagens e mensagens.

\section{ELABORAÇÃO DE MAPAS TURÍSTICOS}

O objetivo inicial da cartografia consiste em expressar, sobre um sistema plano de coordenadas, pontos que tenham perfeita ligação com seu homólogo na superfície terrestre, de tal forma que o cálculo efetuado mantenha perfeita correspondência quando transportado para a superfície original. Essa representação de superfície terrestre sobre o plano, devido a sua facilidade de manejo, interessa sobremaneira nos estudos da topografia, habitação, climatologia, vegetação, turismo etc. O método de projetar ou representar pode ser classificado de duas maneiras: projeção direta, que é a transformação do elipsóide diretamente para a superfície de projeção; e projeção indireta, onde envolve duas transformações, do elipsóide para a esfera e da esfera para a superfície de projeção. Quanto aos tipos de superfície de projeção, subdividem em 
três: plana, cônica e cilíndrica, sendo todas perfeitamente desenvolvíveis no plano (Santos, 1985).

Duarte (1991) subdivide a cartografia em dois grandes ramos: Cartografia Geral e Temática. No primeiro, incluem-se os mapas de uso geral, no segundo, os mapas destinados a público específico ou especial. Entretanto, considera quase impossível traçar uma linha demarcatória para dizer se determinado trabalho constitui preocupação de uma ou de outra. Em seus trabalhos, a Cartografia Temática inicia-se de um "fundo básico" ou "mapa de fundo", que nada mais é do que o conjunto de traços que servirá de suporte para a informação a ser dada sobre determinado tema por meio de simbologia adequada.

Loch, Oliveira, \& Rech (2005) atentam à questão de determinados critérios no que diz respeito à elaboração de um mapa temático, como é caso do mapa turístico, pois, mesmo com todo o aparato tecnológico atual, muitas vezes os mapas não atendem aos critérios da cartografia de base e da cartografia temática. Dessa forma, deve-se buscar uma maior interação entre o mapa e o usuário, ressaltando elementos que vão distinguir o mapa de outro desenho qualquer, como a escala e a projeção cartográfica, coordenadas, legenda ou convenções cartográficas, e do título, nessa ordem de importância.

De modo geral, a constituição de um mapa temático se dá colocando a ideia principal em evidência, mantendo-se, assim, uma harmonia. Deve responder às questões de seu interesse, ser preciso, ter seus elementos de modo organizado, de forma a facilitar a decodificação do receptor. Assim, numa representação cartográfica, o artístico e o científico devem compor um conjunto harmonioso, visando satisfazer o leitor não somente com a estética do trabalho, mas também com o nível das informações fornecidas (Duarte, 1991).

De acordo com Muscarà (como citado em Martinelli, 1996, p. 296), o espaço turístico responde sempre a um intricado complexo de informações, imagens e mensagens. Dessa forma, na construção de um mapa turístico com a finalidade de comunicação, é importante levar em consideração a sua expressividade, isto é, a capacidade de atrair a atenção do leitor aos aspectos nele abordados, valorizando os pontos importantes que estejam relacionados ao tema abordado e destacando as relações hierárquicas do local estudado.

A cartografia utiliza-se de meios, que somados à imagem, auxiliam no processo de comunicação dos mapas, favorecendo a interpretação pelo receptor do que está sendo representado, como: título e subtítulo, que expressa o que está representado no mapa, qual porção da superfície terrestre, qual território e o que está sendo reproduzido, se é hidrografia, relevo, topografia, entre outros; a legenda, extremamente importante por fazer a ligação entre os significantes, gráficos e o significado; a escala, que representa as relações entre as distâncias lineares medidas no terreno, permitindo a precisão dos detalhes em função das necessidades do usuário; as orientações, que são os indicadores cardeais, coordenadas geográficas (latitude, longitude etc.). (Duque, \& Mendes, 2006).

A representação da cartografia do turismo por meio das imagens se torna incontestável, uma vez que esse tipo de registro fixa certas características da realidade, com o propósito de ilustrar o que o texto "diz". Lacoste (1976) salienta a importância de se associar as fotos ou 
desenhos aos mapas, pois estes representam a totalidade do espaço, enquanto a paisagem registrada pelas imagens pode apresentar espaços escondidos em função da disposição do observador. Por outro lado, deve-se atentar a essa prática, pelo fato das imagens fotográficas ou desenhos apresentarem forte caráter polissêmico (significados múltiplos). Dessa forma, surge a necessidade de associar a mesma a um título, slogan ou legenda (Muscarà, 1983, como citado em Martinelli, 1996).

Para uma melhor interpretação, o uso de legendas nas fotografias pode complementar o mapa ou texto turísticos. Muscarà (como citado em Martinelli, 1996) sugere um esquema reduzido colocado ao lado da legenda, identificando e esclarecendo os itens registrados pelo enquadramento da ilustração, como que encaminhando o usuário para uma leitura da paisagem consciente: será decomposta em seus conjuntos paisagísticos mais significativos, organizados em contínuos planos visuais. Desse modo, se torna necessária a inserção de desenhos ou imagens fotográficas aos mapas, para que este possa adquirir maior alcance social no turismo, possibilitando sua interpretação por um número maior de usuários. Loch, Oliveira, \& Rech (2005) apresenta um exemplo do que poderia ser um mapa temático turístico completo, de uma cidade hipotética (Figura 2).

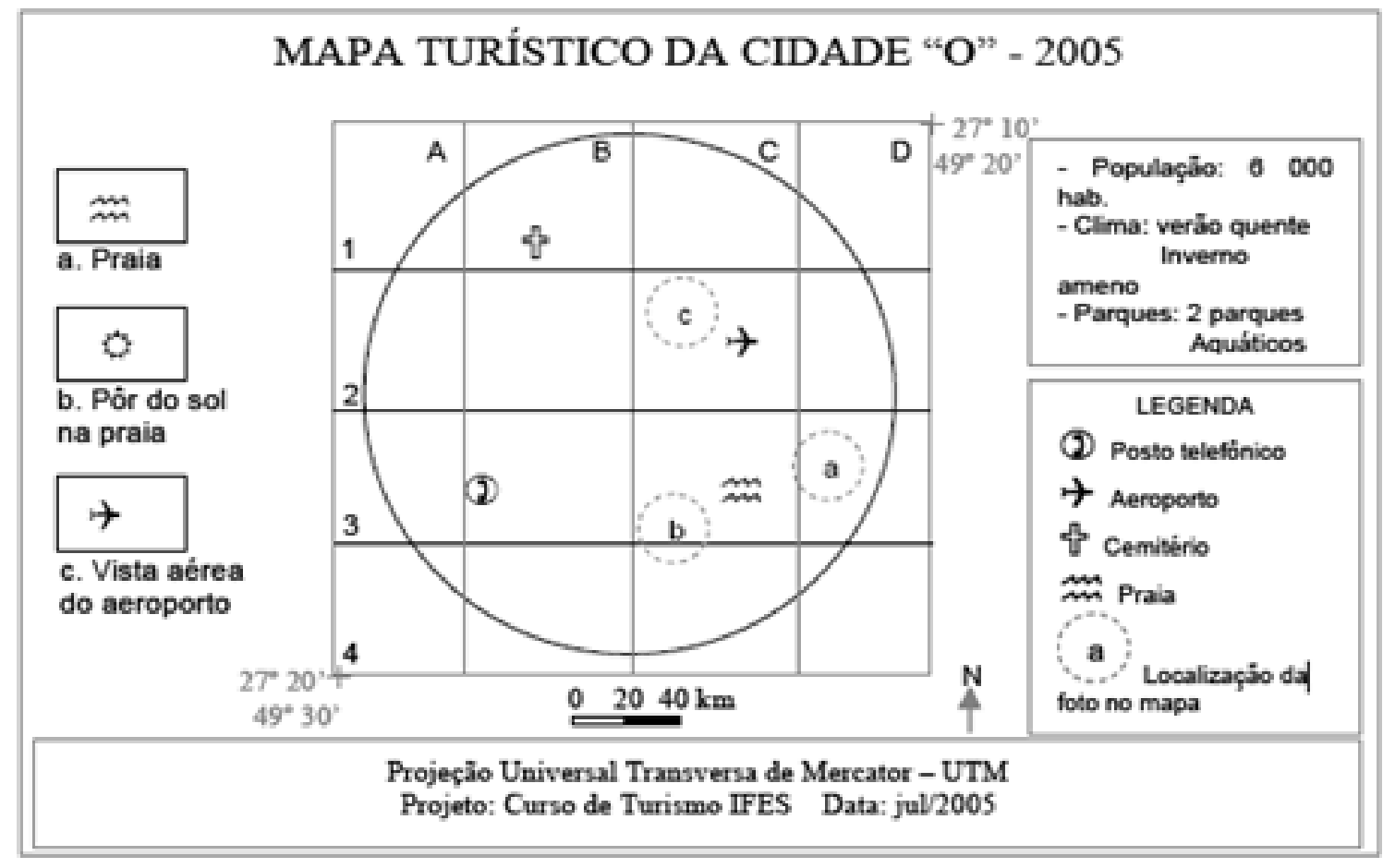

Figura 2. Exemplo de mapa temático turístico Fonte: Loch, Oliveira, \& Rech (2005, p. 12).

Por fim, a cartografia do turismo deve se basear em elementos que contribuam para uma melhor comunicação do produto cartográfico e o turista, mediante coleta, tratamento, análise e representação de dados que possam proporcionar um grande número de informações de 
qualidade e precisão na produção dos mapas. Dessa forma, é desejável que o mapa turístico reúna três formas de comunicação, como mapa, texto e foto, tornando evidente o ponto de encontro equilibrado do sistema semiológico monossêmico (mapa) com os sistemas polissêmicos (texto e foto) (Muscarà, 1983, como citado em Martinelli, 1996).

\section{ANÁLISE EXPLORATÓRIA DOS MAPAS TURÍSTICOS DE OURO PRETO}

A cidade de Ouro Preto está inserida dentre os principais destinos turísticos de Minas Gerais, na região Sudeste do Brasil, e se destaca também no cenário nacional e internacional, conforme dados do Instituto Brasileiro de Turismo (EMBRATUR, online). Localizada a aproximadamente 100 quilômetros de Belo Horizonte, a cidade está na Serra do Espinhaço e se encontra em uma das regiões de maior importância econômica do estado, a Zona Metalúrgica de Minas Gerais (Quadrilátero Ferrífero). Ouro Preto atrai muitos turistas principalmente pela sua história e arquitetura, constituindo o maior conjunto homogêneo de arquitetura barroca do Brasil. O turismo se compõe principalmente pelos segmentos cultural, histórico e turismo de eventos.

Ouro Preto, por apresentar um relevo muito irregular, dificulta a fruição tanto de pedestres e principalmente quanto de veículos. No geral, suas ruas são predominantemente ruelas, possuem minúsculas calçadas e às vezes nem isso. Além disso, existem na cidade becos que se constituem como verdadeiras vilas, com um aglomerado de casas no seu interior, que servem de ligação entre ruas, travessas e até mesmo bairros. Um exemplo disso são os Becos das Rosas e o das Flores, ambos situados no bairro da Barra. Outro exemplo é o Beco do Pilão, localizado entre Câmara Municipal de Ouro Preto e o prédio da Federação das Indústrias do Estado de Minas Gerais (FIEMG), antigo Hotel Pilão, que liga a Praça Tiradentes à Rua dos Paulistas no bairro Antônio Dias. Em sua grande maioria, esses são utilizados somente pela população que tem conhecimento de sua existência.

Em virtude desses fatores é que se propôs fazer o levantamento dos principais mapas turísticos de Ouro Preto, bem como os principais pontos de acesso turístico onde esses mapas são disponibilizados. Os mapas foram selecionados na Secretaria Municipal de Turismo de Ouro Preto, a qual informou a existência de dois tipos de mapas turísticos com maior circulação na cidade. Um é o próprio mapa produzido pela Secretaria de Turismo juntamente com a Prefeitura Municipal de Ouro Preto (Figura 3); o outro é produzido por Walter Peret através da Ponto de Apoio Topografia, encontrado nos principais meios de hospedagem e papelarias da cidade (Figura 4).

Além desses indicados pela referida Secretaria, há um terceiro mapa (Figura 5), associado ao Guia Brasil 4 Rodas, uma vez que esse material é bastante consultado pelos turistas brasileiros e estrangeiros. De acordo com pesquisas realizadas pela Secretaria Estadual de Turismo de Minas Gerais [online], o Guia Brasil 4 Rodas é um mapa muito utilizado pelos turistas pelo fato de conter não somente material cartográfico mas também informações turísticas sobre equipamentos e serviços turísticos em geral, nos mais variados idiomas, principalmente inglês, espanhol e francês.

Uma vez definido o material cartográfico, procurou-se realizar uma análise exploratória do 
mesmo, como tiragem, locais de distribuição, formas de acesso desse material para os turistas e, finalmente, se esses mapas são distribuídos gratuitamente ou não.

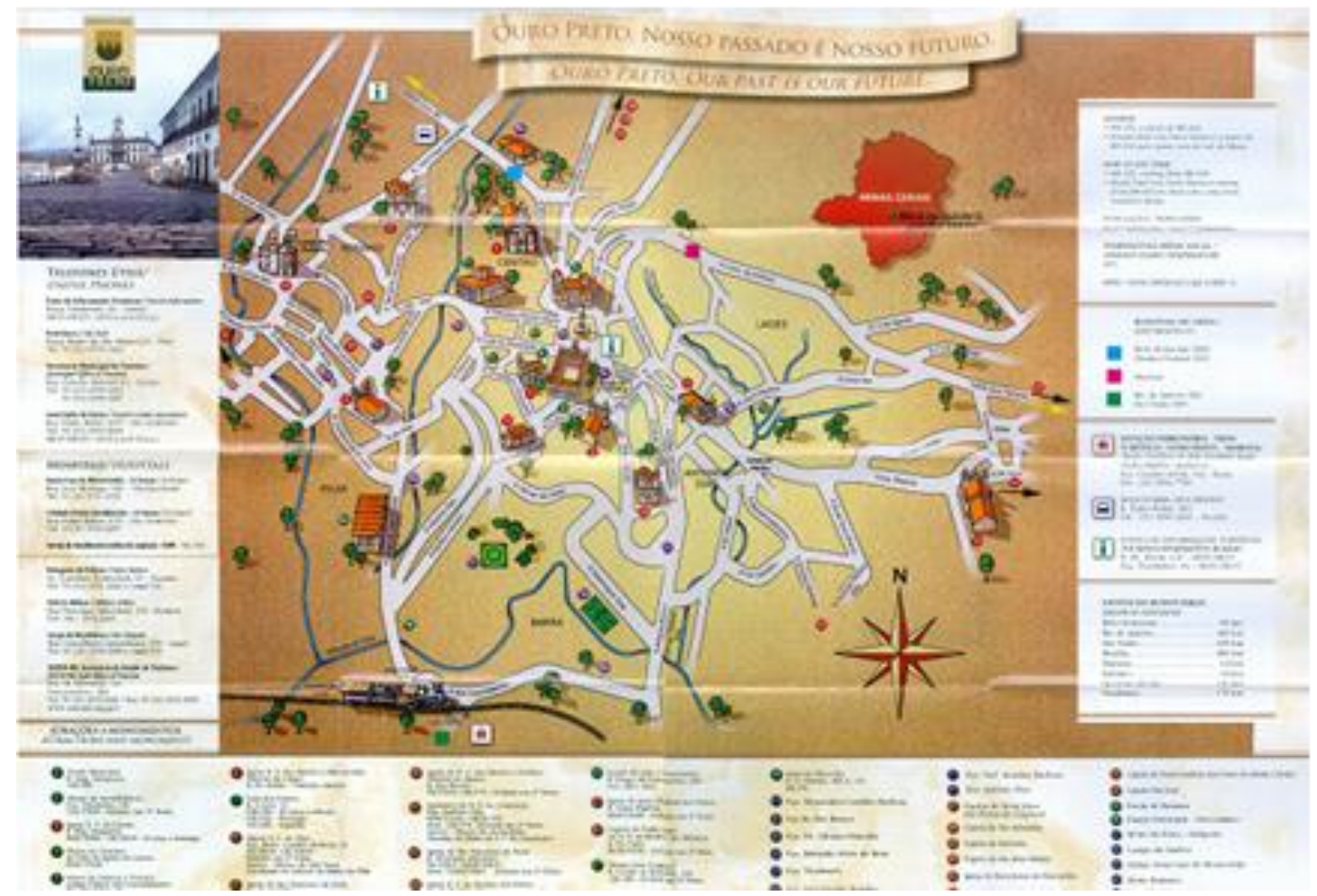

Figura 3. Mapa turístico de Ouro Preto

Fonte: Secretaria Municipal de Turismo de Ouro Preto (2007).

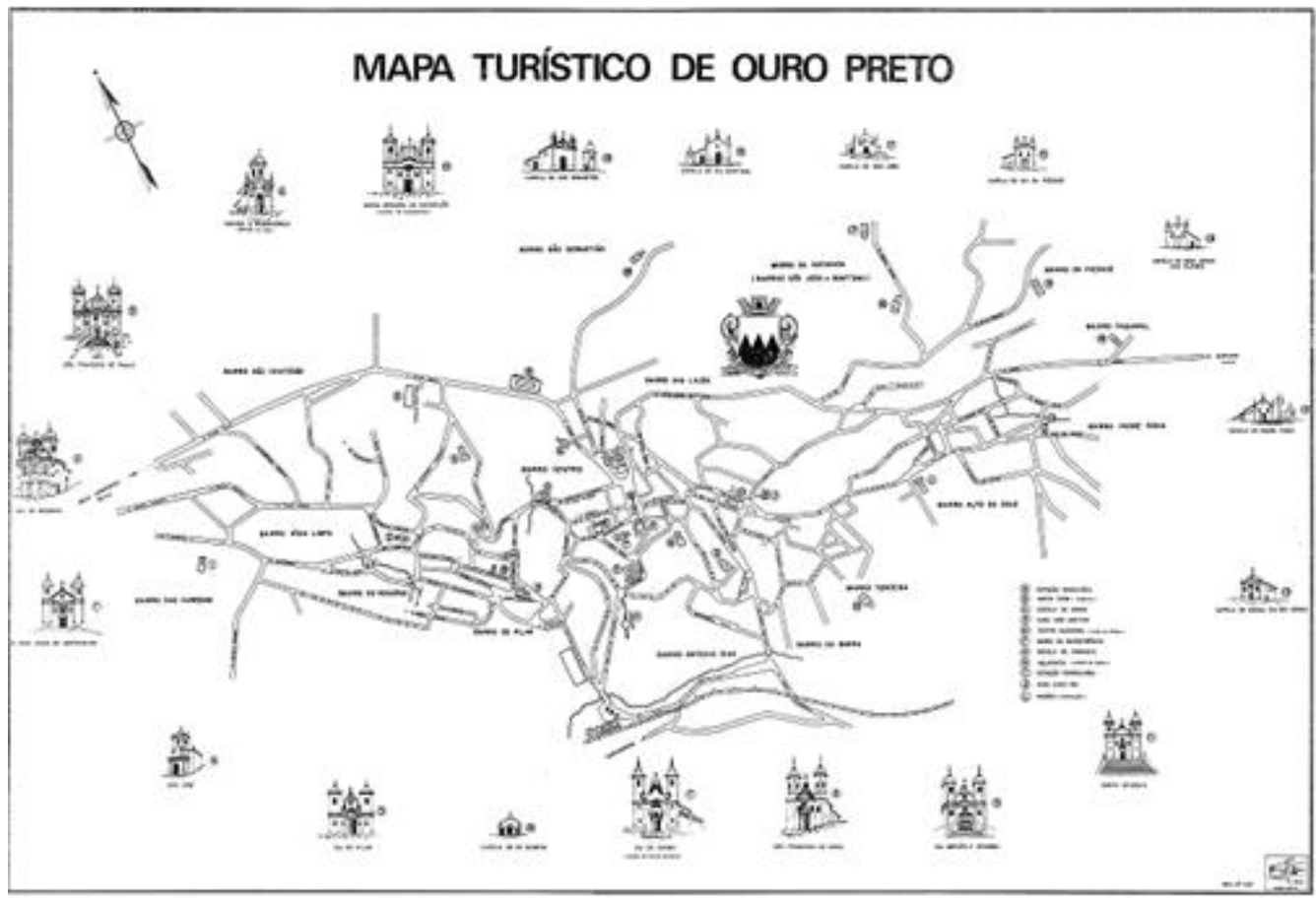

Figura 4. Mapa turístico de Ouro Preto - Meios de hospedagem Fonte: Peret (2008) 
O mapa produzido pela Secretaria Municipal Turismo possui uma tiragem de 50 mil exemplares anualmente, sendo realizadas duas tiragens de 25 mil em cada semestre, e possui distribuição gratuita. Dentre os pontos de distribuição estão: o Centro de Informações Turísticas na entrada da cidade, saída para Belo Horizonte; o Posto de Informações Turísticas da FIEMG, localizado na Praça Tiradentes no prédio da FIEMG; e locais eventuais, como distribuição em congressos e demais eventos onde possa haver demanda dos mesmos.

O mapa produzido pela Ponto de Apoio Topografia possui uma tiragem anual de mil exemplares, e são vendidos aos principais equipamentos e serviços turísticos, como meios de hospedagem e restaurantes da cidade, para serem distribuídos gratuitamente aos turistas; ainda são revendidos em papelarias e armarinhos a um preço de $\mathrm{R} \$ 2,00$ (dois reais) o exemplar.

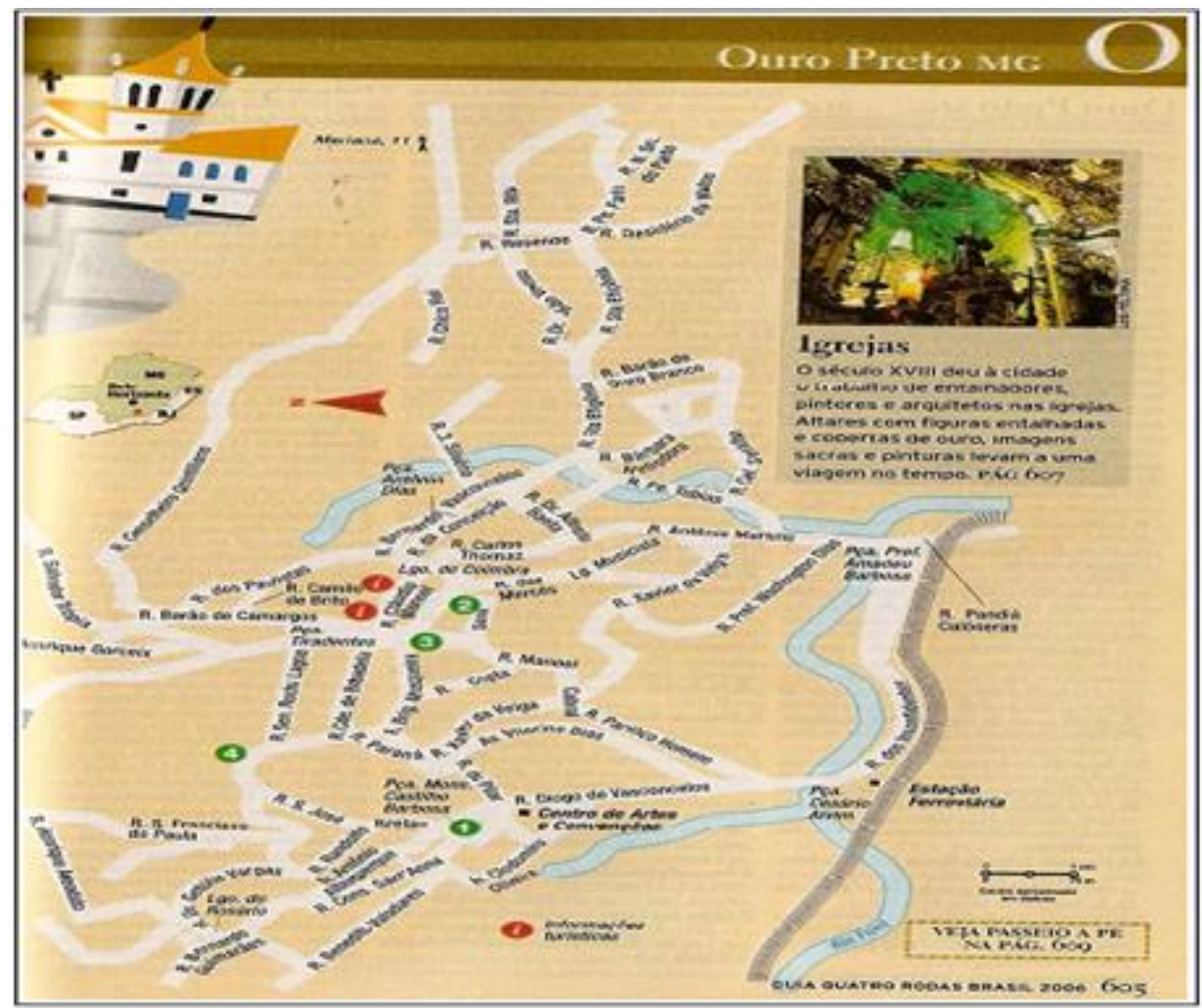

Figura 5. Mapa turístico de Ouro Preto

Fonte: Guia Brasil 4 Rodas (2006, p. 605).

O Guia Brasil 4 Rodas de 2006, de acordo com a Editora Abril de Belo Horizonte, teve uma tiragem de 230 mil exemplares, sendo parte dessa em outros idiomas, e as edições de 2007 e 2008 tiveram uma tiragem de 240 e 250 mil exemplares, respectivamente. Sua distribuição é feita em bancas de jornais e revistas, e vendas na internet pelas grandes editoras do país, onde o usuário pode adquirir o material pelo preço de $\mathrm{R} \$ 35,00$ (trinta e cinco reais) a edição de 2008. 
Dessa forma, através de pesquisa realizada das demais variadas formas, como internet, contato por telefone, contato direto com responsáveis, é que se constatou que esses três materiais cartográficos são de grande relevância no que diz respeito à utilização dos turistas, julgando-se necessária a análise dos mesmos.

Após a pesquisa que possibilitou definir o material cartográfico de interesse, surgiu a necessidade de analisar cada mapa em sua especificidade e, dessa forma, poder compreender o seu contexto por meio dos dados que dispõem.

Portanto, o primeiro material selecionado para essa observação foi o mapa turístico distribuído pela Secretaria Municipal de Ouro Preto. Esse mapa se constitui de uma mini cartilha informativa, contém não somente a representação cartográfica, mas também informações em seu verso como calendário de eventos, telefones úteis da cidade, opções de ecoturismo, indicação de alguns distritos da cidade de Ouro Preto, dicas de como utilizar os produtos turísticos, entre outros. Essas informações, disponibilizadas também no idioma inglês, possibilitam melhor interpretação do local pelo turista e, consequentemente, causam maior interação e empatia entre ele e o mapa (Murta, \& Albano, 2002).

Entretanto, ao possibilitar informações que são de alta relevância para a interpretação, o produtor do mapa suprime outros dados como as coordenadas geográficas e marcação da escala, que orientam o usuário com noções de direção e distância. Duque e Mendes (2006) salientam que o mapa deve direcionar seu usuário, permitindo que o mesmo possa calcular a distância de um ponto ao outro, e dessa forma fazê-lo sentir inserido no espaço turístico. Outra deficiência encontrada foi a ausência do título, pois esse material não se identifica como "mapa turístico", uma vez que é de fundamental relevância apresentar o que está sendo reproduzido no mapa através de seu título e subtítulo.

Julga-se também, de extrema importância, a utilização dos signos iconográficos (imagens) na representação dos pontos turísticos, pois de acordo com Muscarà (como citado em Martinelli, 1996) os mapas que se utilizam de fotografias representativas acabam dispensando o uso da legenda, facilitando sua comunicação. O mapa produzido pela Secretaria de Turismo se utiliza apenas de desenhos que às vezes distorcem a sua forma real (Figura 6).

O segundo material analisado foi o mapa produzido pela empresa de topografia Ponto de Apoio, onde o mesmo se constitui somente como produto cartográfico em si. O mapa é composto de legenda, importante meio que faz a ligação entre significante e significado; título, onde identifica o que está sendo representado no material em questão; imagens dos monumentos religiosos, que apesar de se apresentarem em forma de desenho, conseguem reproduzir com detalhes a realidade, e possuem indicação na legenda; e orientação, onde se encontra no cabeçalho superior esquerdo um indicador cardeal.

Apesar de apresentar itens com grande potencial informativo, esse material cartográfico é destituído de elementos que poderiam contribuir para uma melhor disposição estética e funcional dos seus dados. Mesmo possuindo os indicadores cardeais, o mapa deveria conter na sua composição elementos como as coordenadas geográficas, pois de acordo com Loch, Oliveira e Rech (2005), a falta de tais dados impossibilita a distinção do mapa com outro desenho qualquer. Repetindo o exemplo do primeiro mapa turístico analisado, este não apresenta marcação de escala, o que poderá causar situações indesejadas aos turistas no que diz respeito ao cálculo das distâncias reais. Outro fator encontrado na análise foi a falta de identificação de ruas e becos, em 
locais com pouco fluxo turístico, e também em locais de alto fluxo, como no caso do Centro Histórico da cidade (Figura 7).

Portanto, a ausência na identificação desses elementos como os becos faz com que haja diminuição de possibilidades extras de locomoção dos turistas, e dessa forma extingue a utilização de novos caminhos que possam ser percorridos. Entretanto, quando se identificam todos esses elementos, corre-se o risco do mapa ficar sobrecarregado visualmente, causando dúvidas e confusão de dados na leitura de seus usuários.

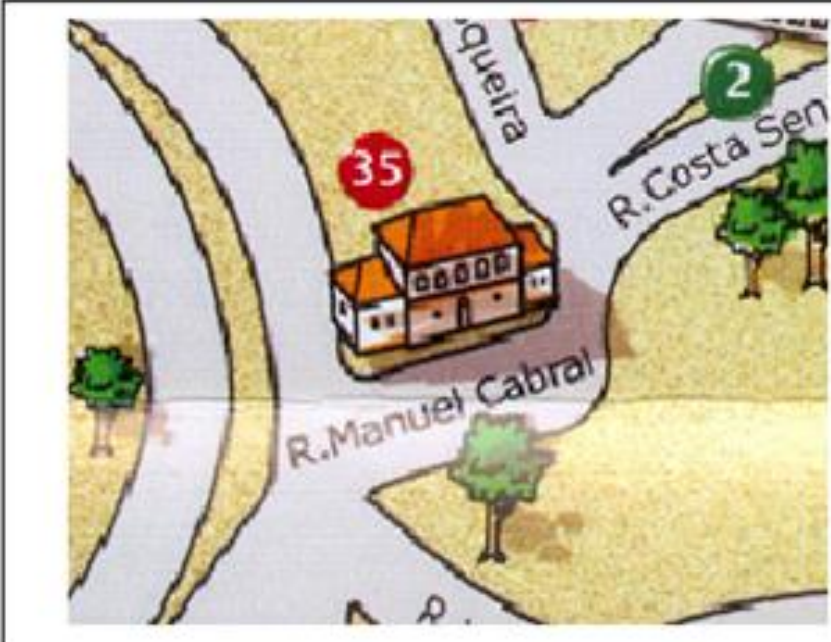

a)

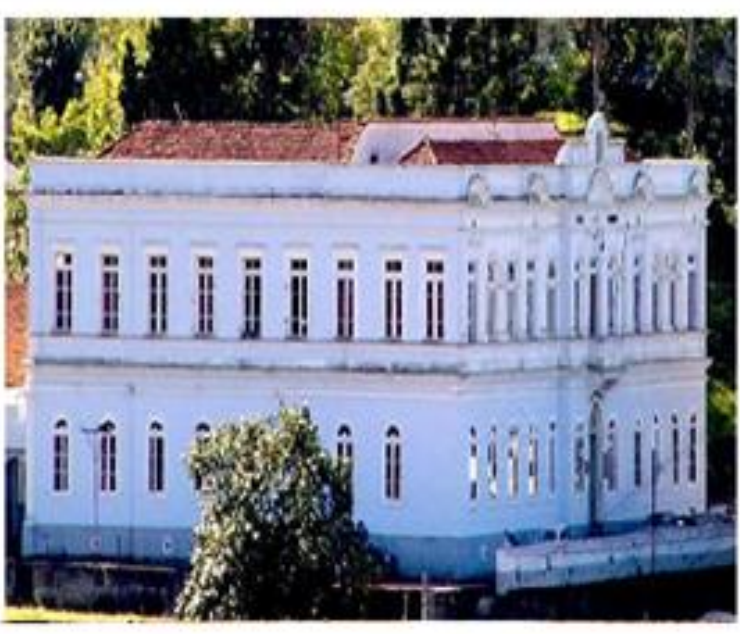

b)

Figura 6. Representação distorcida da Escola de Farmácia de Ouro Preto Fonte: a) Secretaria Municipal de Turismo de Ouro Preto (2007); b) Escola de Farmácia de Ouro Preto [online].

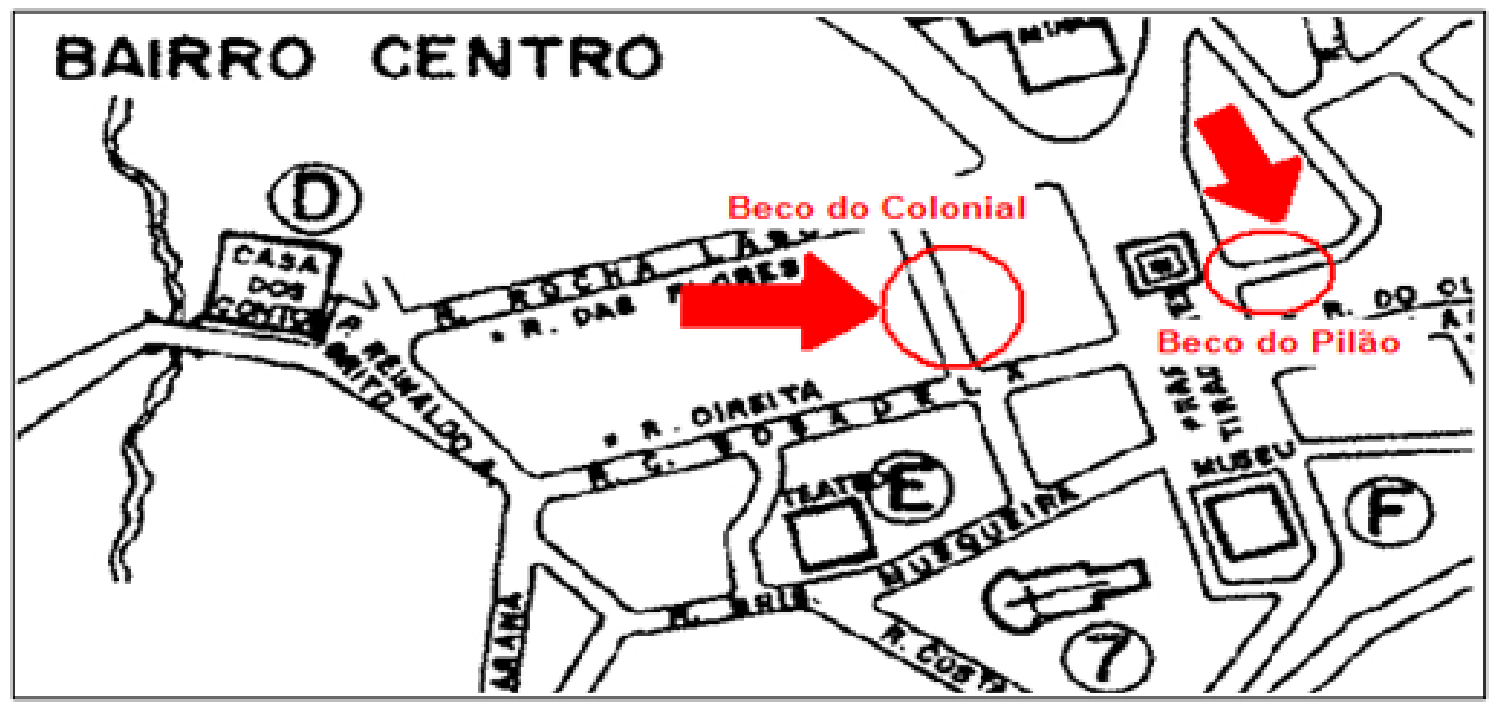

Figura 7. Ausência de identificação dos Becos do Pilão e Colonial no mapa turístico de Ouro Preto Fonte: Peret (2008). 
Finalmente, ao analisar o Guia Brasil 4 Rodas considerou-se não somente o produto cartográfico em si, mas também a sua funcionalidade como um guia turístico. O mapa é constituído de legenda, representando os principais pontos turísticos como monumentos religiosos e museus. Cada igreja e museu representados são complementados por sua respectiva foto em outras páginas do guia, contribuindo para uma maior interpretação da realidade, pois de acordo com Lacoste (1976), essa associação atração imagem representa a totalidade do espaço de forma mais completa; possui indicador cardeal no que diz respeito à sua localização; e é composto de marcação de escala, fator importante na identificação do material representado em sua constituição como um mapa (Loch, Oliveira, \& Rech, 2005).

No que diz respeito às suas deficiências, o mapa não possui título e dessa forma não se denomina como material cartográfico, apesar de seu contexto estar inserido em um guia turístico. Também não são apresentadas coordenadas geográficas, que quando associadas aos indicadores cardeais, compõem um importante meio para localização dos seus usuários. Por fim, além de não identificar elementos como ruas e becos, exclui a própria existência dos mesmos, como exemplificado na Figura 8. A omissão desses fatores causa, na mesma intensidade do excesso, dúvidas para quem se utiliza desse mapa, com a consequente perda de credibilidade por parte de esses usuários.

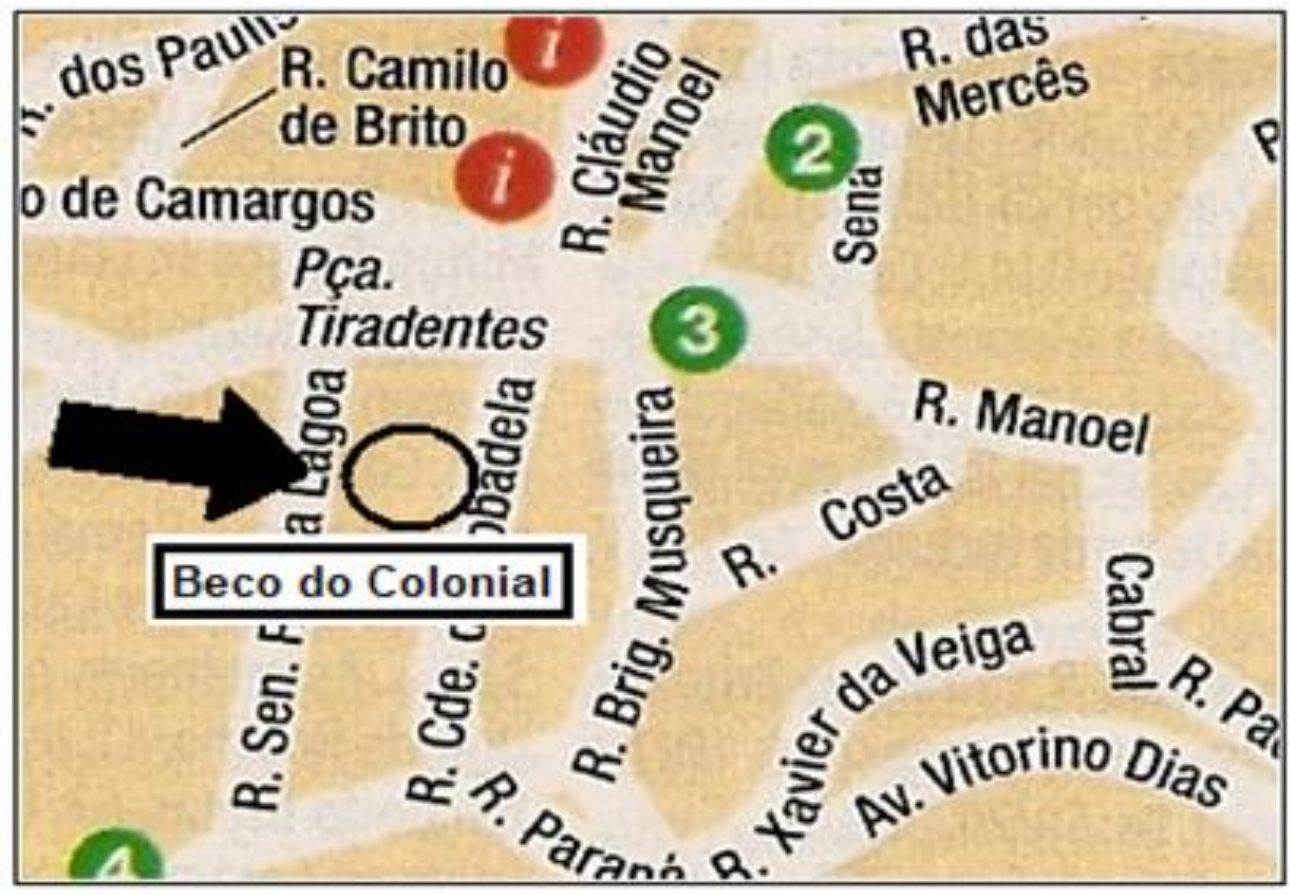

Figura 8. Omissão do Beco do Colonial no Mapa turístico de Ouro Preto Fonte: Guia Brasil 4 Rodas (2006, p. 605).

Em virtude dos fatores mencionados, os três mapas analisados apresentam fatores positivos e negativos na sua constituição. Dessa forma, propõe-se elaborar um material cartográfico com o intercâmbio de todas as informações positivas encontradas nesses materiais 
em questão, ou seja: título e subtítulo; legenda de todos os elementos representativos; escala numérica; indicadores cardeais, coordenadas geográficas; e principalmente elementos semiológicos (imagens). Desse modo, poder-se-á associar todas essas características por meio de uma disposição harmônica para, assim, evitar sobreposição e, consequentemente, dúvidas ou dados confusos na sua interpretação.

\section{CONSIDERAÇÕES FINAIS}

A interpretação dos espaços requer de seu agente, em suas mais variadas formas, um grande esforço para tal, uma vez que são envolvidos fatores culturais, históricos, físicos, dentre outros. E no espaço turístico, ao ser representando pela cartografia, salienta-se a sua interpretação pelo viés da comunidade local e do turista, pois dessa forma pode ser concebida a realidade da primeira e os anseios lúdicos do segundo. Apesar dos mapas analisados serem de 2006 a 2008, refletem aspectos que se apresentam até o momento em muitas outras localidades turísticas, razão pela qual a relevância deste artigo se mantém.

A partir do desenvolvimento do presente trabalho, pode-se concluir que os objetivos traçados foram atingidos, ou seja, o levantamento dos mapas turísticos de Ouro Preto de maior abrangência e seus locais de divulgação, bem como a análise dos seus fatores positivos e negativos. No mais, o entendimento da contextualização do mapa turístico e seus componentes foram também contemplados e desenvolvidos dentro do conceito turístico. Para tanto, alguns conceitos cartográficos e simbológicos foram discutidos no que tange á confiabilidade da comunicação cartográfica das informações turísticas. Dessa forma, a metodologia proposta seguiu conceitos pesquisados sobre o assunto e mostrou que, apesar de existirem variados produtos cartográficos turísticos de Ouro Preto, os materiais analisados se destacam dentre todos pela quantidade do público atingido.

A análise dos materiais cartográficos turísticos de Ouro Preto provou que os mesmos possuem deficiências em sua elaboração, omitindo elementos que são de fundamental importância para uma perfeita comunicação do mapa com o turista. Entretanto, como a Cartografia Turística (Menezes, \& Fernandes, 2008) possui inúmeras potencialidades, é que se recomenda a atualização desse trabalho em curto prazo. Assim, para que este não se prenda a antigos conceitos cartográficos e que possa ser aplicado a outras destinações turísticas. Além disso, uma entrevista com os produtores desses mapas seria de grande relevância para obter informações detalhadas dos mesmos.

Finalmente, ao fornecer embasamento teórico para que se desenvolva um mapa turístico, recomenda-se como proposta futura a produção de um mapa turístico de pretensão ideal. Dessa forma, testar esse mapa mediante pesquisa de campo levando um grupo de turistas a interagir com o mesmo e, assim, avaliar os resultados obtidos, seria de grande contribuição na continuidade dessa pesquisa. 
Assim sendo, a Cartografia do Turismo consegue agregar dois conceitos: arte e ciência. Ciência por estar a serviço de várias outras ciências, por constituir um conjunto de operações como a transformação da superfície curva da Terra até a busca da melhor simbologia para representar os mais variados fatos dessa mesma superfície. Arte pelo fato do cartógrafo buscar oferecer uma informação do modo mais adequado, por meio da linguagem gráfica, respeitando as regras da semiologia gráfica e sem esquecer-se da ótica da estética, visando atingir o ideal de beleza, mas sempre buscando harmonia entre o artístico e o científico.

\section{REFERÊNCIAS}

Aguilar, J. (1967). Georama. (2ª ed.). Rio de Janeiro: Codex.

Cáceres, F. (1996). História geral. (4a ed.). São Paulo: Moderna.

Chaui, M. (1997). Convite à filosofia. (8a ed.). São Paulo: Ática.

Duarte, P. A. (1991). Cartografia temática. Florianópolis: Ed. UFSC.

Duque, R. C., \& Mendes, C. L. (2006). O planejamento turístico e a cartografia. Campinas: Alínea.

EMBRATUR. Instituto Brasileiro de Turismo. [online]. Portal Brasileiro do Turismo. Apresenta produtos e serviços turísticos oferecidos pelo Brasil. Recuperado em 19 junho, 2008, de http://www.braziltour.com/site/br/cidades/materia.php?id_cidade=1055.

Escola de Farmácia de Ouro Preto. [online]. Recuperado em 25 junho, 2008, de http://www.ef.ufop.br/.

Guia Brasil 4 Rodas. (2006). Mapa Turístico de Ouro Preto. Ouro Preto: Ed. Abril.

Lacoste, Y. (1976). La géographie ça sert d'abord pour faire la guerre. Paris: Maspero.

Loch, R. E. N., Oliveira, K. N., \& Rech, C. M. C. B. (2005). Orientações para elaborar um mapa temático turístico. Recuperado em 12 junho, 2008, de

http://www2.ifes.com.br/webifes/revista/Files/ORIENTA\%C7\%D5ES\%20PARA\%20ELABORAR\%20UM\%20M APA\%20TEM\%C1TIC.pdf.

Martinelli, M. (1996). Cartografia do turismo: que cartografia é essa? In Lemos, I. G. Turismo: Impactos socioambientais. São Paulo: Hucitec.

Menezes, P. M. L., \& Fernandes, M. C. (2008). Cartografia turística: novos conceitos e antigas concepções ou antigos conceitos e novas concepções. Revista Brasileira de Cartografia, 1(60). Recuperado em 13 junho, 2008, de http://www.rbc.ufrj.br/_2008/60_1_01.htm.

Morandi, S., \& Gil, I. C. (2002). Espaço e turismo. (2ª ed.). São Paulo: Copidart.

Murta, S. M., \& Albano, C. (2002). Interpretar o patrimônio: um exercício do olhar (pp. 131-138). Belo Horizonte: Ed. UFMG, Território Brasilis.

Pereira, A. C. F., Dias, L. A. V., \& Damolin, Q. (1999). Elaboração de símbolos cartográficos para mapas turísticos em meio digital. Boletim de Ciências Geodésicas, 5, 3-14.

Peret, W. (2008). Mapa turístico de Ouro Preto. Ouro Preto.

Santos, A. A. (1985). Representações cartográficas. Recife: Ed. UFPE. 
Secretaria Estadual de Turismo de Minas Gerais. [online]. Guia 4 Rodas de Minas Gerais servirá como fonte de pesquisa para turistas e operadores do segmento. Recuperado em 13 junho, 2008, de http://www.turismo.mg.gov.br/index.php?option=com_content\&task=view\&id=7.

Secretaria Municipal de Turismo de Ouro Preto. (2007). Mapa turístico de Ouro Preto. Ouro Preto.

Artigo recebido em: $24 / 03 / 2011$.

Artigo aprovado em: 19/04/2012. 